\title{
ROLE OF THE AUTONOMIC NERVOUS SYSTEM IN THE REGULATION OF PHOSPHORUS AND CALCIUM METABOLISM IN COWS
}

O. V. ZHURENKO, Doctor of Veterinary Sciences, Associate Professor, Department of Animal Biochemistry and Physiology named after Academician M. F. Gulyi https://orcid.org/0000-0002-4933-0372

V. I. KARPOVSKYI, Doctor of Veterinary Sciences, Professor, Department of Animal Biochemistry and Physiology named after Academician M. F. Gulyi https://orcid.org/0000-0003-3858-0111

V. V. ZHURENKO, Candidate of Veterinary Sciences, Department of Animal Biochemistry and Physiology named after Academician M. F. Gulyi

https://orcid.org/0000-0003-2097-9212

National University of Life and Environmental Sciences of Ukraine, 15 Heroiv

Oborony st., Kyiv 03041, Ukraine

E-mail: Zhurenko-lena@ukr.net

\begin{abstract}
The leading role in the mobilization of the organism adaptive capabilities is played by neuro-humoral mechanisms, primarily the activity of the central nervous system. The full-fledged mineral nutrition of cattle depends on the animal supply with macroelements, which are included in the structure of many enzymes or are their activators, taking a leading role in redox reactions. The studies were carried out on cows of the Ukrainian black-spotted dairy breed of 2-3rd lactation. By the results of studying the autonomic nervous system tone, 3 experimental groups were formed: 1 - normotonics, 2 -vagotonics, 3 - sympathicotonics. Blood from cattle was collected twice a year in summer and winter. Whole blood was stabilized with heparin, blood serum was obtained by sedimentation method, and blood cells - by centrifugation of heparinized blood, plasma collection and after triple washing of cells in the cold isotonic solution, followed by centrifugation. The tone of the autonomic nervous system in cows in summer is inversely related to the content of phosphorus in whole blood ( $r=-0.73 ; P<0.05)$ and blood cells $(r=-0.87 ; P<0.001)$. However, in blood serum, these relationships are unreliable both in summer and winter ( $r=$ -0.02-0.24). In winter, the tone of the autonomic nervous system in cows is inversely reliably associated only with phosphorus content in whole blood $(r=-0.81 ; P<0.01)$. Unlike the tone of the autonomic nervous system, the season has a significant effect on calcium content in whole blood $(F=8.94>F U=8.41 ; P<0.01)$, while the content of this element in serum and blood cells of cows did not depend from the season. So, the tone of the autonomic nervous system and the season affect the content of calcium and phosphorus in blood of cows.
\end{abstract}

Keywords: cows, blood, nervous processes, the tone of the autonomic nervous system, calcium, phosphorus 


\section{Introduction}

The current state of the agricultural industry is due to the global impact of modernization, which is accompanied by an increase in the technogenic load on animals. The leading role in the mobilization of the adaptive capabilities of the organism is played by neuro-humoral mechanisms, primarily the activity of the central nervous system (Pogorlov, 2010). Studies on the influence of the higher nervous activity type in cows on the mineral status of the animal's organism are of scientific and practical interest. The full-fledged mineral nutrition in cattle depends on the animal supply with macroelements, which are included in the structure of many enzymes or are their activators, taking a leading role in redox reactions (Guyot et al., 2012). Macroelements, despite their low content in the body, play a significant biological role (Byts, 2010; Gromova et al., 2010). In addition to the general positive effect on the processes of growth and development, the specific effect of several macroelements on the most important physiological processes has been established; their significance is also explained by their interaction with biologically active substances - hormones and vitamins (Zakharenko, 2004). The optimal content and ratio of essential trace elements in the animal's organism determine the normal course of their physiological functions, high resistance, and productivity (Kalyn, 2011). The absence or deficiency of individual mineral elements, as well as their suboptimal ratio in the diets, leads to a decrease in the efficiency of feed nutrients and, as a consequence, to a decrease in livestock productivity.

\section{Analysis of recent researches and publications}

It is known that metabolic processes at the cellular and subcellular levels are provided by the functioning of about 2000 enzymes, each of which catalyzes a corresponding chemical reaction (Gapon, 2005). In turn, the catalytic activity of enzymes is provided by coenzymes of non-protein origin - organic compounds or inorganic elements (metal ions - macro- and microelements). Despite the fact that minerals have no energy value, like proteins, fats, and carbohydrates, many enzymatic processes in the body are impossible without certain elements. Macroelements play a key role in maintaining acid-base balance, osmotic pressure, membrane potential, and transmission of nerve stimuli. The conducted research has established a reliable influence of the main characteristics of cortical processes on the content of macroelements in bovine blood (Avtsyn, 1991). The macroelement content in the body is quite stable, even relatively large deviations from the norm are compatible with the vital activity of the organism. The main process of absorption of macro- and microelements occurs in the upper part of the small intestine, namely in the duodenum. Regulation is carried out under the effect of the central and autonomic nervous system, and the endocrine system. However, insufficient attention is paid to the study of the individual characteristics of mineral homeostasis in the body of productive cows in an intact and stressed state (McDowell, 2003; Zinko, 2017). Determination of individual characteristics of higher nervous activity in animals provides a deeper understanding of the cortical mechanisms in the regulation of various physiological functions, creating the prerequisites for a targeted impact on them (Skalny, 2004; Danchuk et al., 2017).

\section{Materials and methods of research}

The studies were carried out on cows of the Ukrainian black-spotted dairy breed of the 2-3rd lactation. By the results of 
studying the tone of the autonomic nervous system, 3 experimental groups were formed (5 animals in each): 1 - normotonic, 2 - vagotonic, 3 - sympathicotonic cows. Research material was blood samples from cattle taken from the jugular vein in the morning before feeding. Blood was collected twice a year in summer and winter. Whole blood was stabilized with heparin, blood serum was obtained by sedimentation method, and blood cells - by centrifugation of heparinized blood, plasma collection and after triple washing of cells in the cold isotonic solution, followed by centrifugation (Vlizlo et al., 2012). The obtained digital data were processed statistically using the applied software package "Microsoft Office Excel 2013". The arithmetic mean value (M) and its error (m) were determined. The probability of differences in mean values was determined by the Student's test. Parameters changes were considered significant at $\mathrm{P}<0.05$ (including $\mathrm{P}<0.01$ and $\mathrm{P}<0.001$ ).

\section{Research results and their discussion}

The studies showed that in animals with a different tone of the autonomic nervous system the phosphorus content in various blood fractions did not exceed physiological limits (Table 1).

In particular, the phosphorus content in bovine whole blood depending on the vegetative status and season was 20.5-25.0 mg/100 mL, in blood serum - 10.9-12.1 mg/100 mL, and in blood cells $-47.1-52.5 \mathrm{mg} / 100 \mathrm{~mL}$. It was found that both in warm and cold seasons the phosphorus content did not differ significantly in different blood fractions of normotonics and vagotonics.

In sympathicotonic animals, in the warm season, the phosphorus content was lower in whole blood by $11.8 \%$
( $\mathrm{P}<0.001)$, and in blood cells - by $8.2 \%(\mathrm{P}<0.001)$ in comparison with indicators in normotonic cows.

Whereas in the cold season, the phosphorus content was significantly lower in whole blood by $16.0 \%(\mathrm{P}<0.001)$ and in blood cells - by $6.4 \%(\mathrm{P}<0.001)$ compared with indicators in normotonic cows. It should be noted that time of the year affects the phosphorus content in various fractions of bovine blood.

So, regardless of the vegetative status in cows, in the cold season, the phosphorus content in blood serum is $7.2-9.4 \%$ lower $(\mathrm{P}<0.05-0.01)$ compared with the indicator of these animals in summer. In addition, in sympathicotonic cows, the content of this metal in whole blood in winter is significantly lower (by $6.8 \%$; $\mathrm{P}<0.05$ ) compared with the indicator in these animals in summer. But the phosphorus content in blood cells of these animals in warm and cold seasons does not differ significantly.

Studies showed that in animals with a different tone of the autonomic nervous system, the content of inorganic phosphorus in the blood serum did not exceed physiological levels and, depending on the vegetative status of animals and season, was $4.6-5.1 \mathrm{mg} / 100 \mathrm{~mL}$. It was found that both in warm and cold seasons in different blood fractions of normotonics and vagotonics, the content of inorganic phosphorus in blood serum did not differ significantly. However, in the warm season, the content of inorganic phosphorus in the blood serum in sympathicotonic animals was lower by $5.7 \%(\mathrm{P}<0.05)$ and in the cold seasonby $5.6 \%(\mathrm{P}<0.05)$ compared with indicators in normotonic cows. It should be noted that the season affects inorganic phosphorus content in bovine serum. Thus, in normotonic, vagotonic, and sympathicotonic cows in the cold season, this indicator was $6.0-7.7 \%(\mathrm{P}<0.05)$ lower than in these animals in the warm season. 
1. Phosphorus content in blood of cows with different vegetative status depending on the season, $\mathrm{mg} / 100 \mathrm{~mL}(\mathrm{M} \pm \mathrm{m}, \mathrm{n}=5)$

\begin{tabular}{|l|c|c|c|}
\hline \multirow{2}{*}{\multicolumn{1}{|c|}{ Substrate }} & \multicolumn{3}{c|}{ Vegetative status } \\
\cline { 2 - 4 } & normotonic & vagotonic & sympathicotonic \\
\hline Blood serum & $24.98 \pm 0.23$ & $24.30 \pm 0.35$ & $22.03 \pm 0.26^{* * *}$ \\
\hline Whole blood & $12.08 \pm 0.19$ & $11.98 \pm 0.17$ & $11.78 \pm 0.33$ \\
\hline Blood cells & $51.15 \pm 0.60$ & $52.45 \pm 0.26$ & $46.98 \pm 0.89^{* * *}$ \\
\hline \multicolumn{4}{|c|}{ Winter } \\
\hline Blood serum & $24.43 \pm 0.46$ & $23.58 \pm 0.60$ & $20.53 \pm 0.30^{* * *}$ \\
\hline Whole blood & $11.20 \pm 0.34$ & $10.85 \pm 0,40$ & $10.88 \pm 0.37$ \\
\hline Blood cells & $50.30 \pm 0.60$ & $50.70 \pm 0.95$ & $47.08 \pm 0.28^{* * *}$ \\
\hline
\end{tabular}

Note: differences are significant in comparison with normotonics: $* \mathrm{P}<0.05 ; * * \mathrm{P}<0.01$; $* * * \mathrm{P}<0.001$.

The studies have established the influence of the vegetative status in cows on the phosphorus content in blood depending on the season.

The predominance of the influence of the parasympathetic division of the autonomic nervous system on the heart, both in summer and in winter, does not affect phosphorus content in whole blood, serum, and blood cells in cows $\left(\eta^{2} x=\right.$ $0.02-0.40)$. The predominance of the sympathetic part of the autonomic nervous system influence on the work of the heart in summer affects the phosphorus content in bovine whole blood $-\eta^{2} \chi=0.92$ $(\mathrm{P}<0.001)$ and blood cells $-\eta_{\chi}^{2}=0.72$ $(\mathrm{P}<0.01)$. In winter, the influence of the tone of the autonomic nervous system in sympathicotonic cows on the phosphorus content in whole blood and blood cells stayed significant $\left(\eta_{\chi}^{2}=0.80-0.89\right.$ $(\mathrm{P}<0.01-0.001)$. The relationship of the autonomic nervous system in cows with phosphorus content in their blood depending on the season has been established.

Thus, the tone of the autonomic nervous system in cows in summer is inversely reliable related to phosphorus content in whole blood $(\mathrm{r}=-0.73 ; \mathrm{P}<0.05)$ and its cells $(\mathrm{r}=-0.87 ; \mathrm{P}<0.001)$. However, in blood serum, these relationships are unreliable both in summer and winter $(\mathrm{r}=-0.02-0.24)$. In winter, the tone of the autonomic nervous system in cows is inversely reliable related only to phosphorus content in whole blood $(\mathrm{r}=-0.81 ; \mathrm{P}<0.01)$. Thus, regardless of the season, the changes in heart rate difference according to the results of the trigeminovagal test in cows by one unit, the phosphorus content in whole blood changes in the opposite way by $0.09-0.12 \mathrm{mg} / 100 \mathrm{~mL}$ ( $\mathrm{P}<0.05-0.01)$. Moreover, up to $53 \%$ $(\mathrm{P}<0.01)$ in summer and up to $48 \%$ $(\mathrm{P}<0.05)$ variations in the content of this metal in whole blood of cows in winter can be caused by the tone of the autonomic nervous system of animals.

Regardless of the season, the changes in heart rate difference according to the results of the trigeminovagal test in cows by one unit, the phosphorus content in the blood cells changes in the opposite way by $0.15-0.21 \mathrm{mg} / 100 \mathrm{~mL}(\mathrm{P}<0.001)$. In addition, up to $75 \%(\mathrm{P}<0.001)$ in summer and up to $66 \%(\mathrm{P}<0.001)$ variations in the content of this metal in blood cells in winter can be caused by the tone of the autonomic nervous system of animals. It should be 
noted that regression analysis did not show a reliable dependence of phosphorus content in blood serum on the vegetative status of animals. It was found that the tone of the autonomic nervous system and phosphorus content in blood serum of cows did not shown a significant relationship $(\mathrm{F}=0.53$ $<\mathrm{FU}=3.55 ; \mathrm{P}<0.05)$, while the content of this element in whole blood $(\mathrm{F}=43.0>$ $\mathrm{FU}=3.55 ; \mathrm{P}<0.001)$ and blood cells $(\mathrm{F}=$ $27.5>\mathrm{FU}=3.55 ; \mathrm{P}<0.001)$ depends on the vegetative status. Unlike the tone of the autonomic nervous system, the season has no significant effect on phosphorus content in blood cells of cows $(\mathrm{F}=2.44<\mathrm{FU}=4.41$; $\mathrm{P}<0.05)$, while its effect on phosphorus content in whole blood $(\mathrm{F}=8.54>\mathrm{FU}=$ $4.41 ; \mathrm{P}<0.01)$ and its serum $(\mathrm{F}=14.4>$ $\mathrm{FU}=4.41 ; \mathrm{P}<0.001)$ is significant. It should be noted that analysis of phosphorus content in whole blood, serum, and blood cells of cows showed no reliable interaction between the vegetative status and season of the year $(\mathrm{F}=0.10-1.00<\mathrm{FU}=3.55 ; \mathrm{P}<0.05)$.

The studies showed that in animals with a different tone of the autonomic nervous system, the calcium content in various blood fractions did not exceed the physiological limits (Table 2).

In particular, the calcium content in whole blood of cows, depending on the vegetative status and season, was 5.0-5.6 $\mathrm{mg} / 100 \mathrm{~mL}$, in blood serum $7.7-8.5 \mathrm{mg} / 100 \mathrm{~mL}$, and in blood cells $2.3-2.6 \mathrm{mg} / 100 \mathrm{~mL}$.

It was found that in the warm season, the calcium content in blood cells of vagotonics is significantly higher by $10.4 \%$ $(\mathrm{P}<0.05)$ in comparison with the indicators in normotonic animals. In addition, in summer, the content of ionized calcium in vagotonics is significantly lower by $4.6 \%$ $(\mathrm{P}<0.05)$ compared to the indicators of normotonic animals. However, the content of this macroelement in whole blood and serum did not differ significantly.
Unlike the indicators in vagotonic animals, in blood serum of sympathicotonic cows, the content of ionized calcium in summer was $7.3 \%$ higher $(\mathrm{P}<0.05)$ than that in cows with normotonia, and calcium content in blood cells was higher by $12.4 \%$ $(\mathrm{P}<0.05)$ than in normotonics. It should be noted that the ratio of ionized calcium content to total one in blood of sympathicotonic cows in summer is $6.3 \%(\mathrm{P}<0.05)$ higher than that in normotonic cows.

This indicator did not differ significantly from that one in normotonic cows in the cold season. Besides, in sympathicotonic cows, the only calcium content in blood cells significantly differs from the indicators of normotonic animals in the cold season (higher by $8.3 \%, \mathrm{P}<0.05$ ).

It should be noted that the time of the year affects calcium content in whole blood of cows. Thus, calcium content in whole blood of vagotonic and sympathicotonic cows in the cold season is lower by $9.6 \%$ $(\mathrm{P}<0.05)$ and $7.1 \%(\mathrm{P}<0.05)$, respectively, than in these animals in summer. But calcium content in other blood fractions in these animals in warm and cold seasons does not differ significantly.

The influence of the vegetative state of cows on blood calcium content depending on the season has been established.

The predominance of the influence of both the sympathetic and the parasympathetic divisions of the autonomic nervous system on the work of the heart in summer affects calcium content in blood cells of cows $-\eta_{\chi}^{2}=0.58-0.65$ $(\mathrm{P}<0.05)$. Along with this, the effect of the autonomic nervous system tone on the content of ionized calcium in blood serum of cows was established $-\mathrm{n}_{\chi}^{2}=$ $0.65-0.70(\mathrm{P}<0.05-0.01)$.

Thus, the tone of the autonomic nervous system in cows in summer is significantly directly related to the content of ionized calcium in blood serum $(r=0.87$; 
2. Calcium content in blood of cows with different vegetative status depending on the season, $\mathrm{mg} / 100 \mathrm{~mL}(M \pm \mathrm{m}, \mathrm{n}=\mathbf{5})$

\begin{tabular}{|l|c|c|c|}
\hline \multirow{2}{*}{\multicolumn{1}{|c}{ Substrate }} & \multicolumn{3}{c|}{ Vegetative status } \\
\cline { 2 - 4 } & normotonic & vagotonic & sympathicotonic \\
\hline Whole blood & $5.27 \pm 0.12$ & $4.98 \pm 0.18$ & $5.26 \pm 0.12$ \\
\hline Blood serum & $8.10 \pm 0.11$ & $7.69 \pm 0.28$ & $8.17 \pm 0.20$ \\
\hline Blood cells & $2.30 \pm 0.07$ & $2.54 \pm 0.05^{*}$ & $2.58 \pm 0.05^{*}$ \\
\hline Ionized Ca & $3.46 \pm 0.04$ & $3.3 \pm 0.03^{++}$ & $3.71 \pm 0.06^{*}$ \\
\hline Ionized Ca/total Ca & $0.43 \pm 0.01$ & $0.43 \pm 0.01$ & $0.45 \pm 0.01^{*}$ \\
\hline \multicolumn{3}{|c|}{ Winter } \\
\hline Blood serum & $5.43 \pm 0.16$ & $5.46 \pm 0.16$ & $5.63 \pm 0.03$ \\
\hline Whole blood & $8.34 \pm 0.35$ & $8.27 \pm 0.32$ & $8.51 \pm 0.03$ \\
\hline Blood cells & $2.36 \pm 0.05$ & $2.40 \pm 0.05$ & $2.56 \pm 0.03 * *$ \\
\hline Ionized Ca ${ }^{++}$ & $3.60 \pm 0.17$ & $3.42 \pm 0.14$ & $3.68 \pm 0.03$ \\
\hline Ionized Ca/total Ca & $0.43 \pm 0.01$ & $0.41 \pm 0.01$ & $0.43 \pm 0.01$ \\
\hline
\end{tabular}

Note: differences are significant in comparison with normotonics: $* \mathrm{P}<0.05 ; * * \mathrm{P}<0.01$; $* * * \mathrm{P}<0.001$.

$\mathrm{P}<0.001)$ and the ratio of ionized calcium to total one in blood serum $(\mathrm{r}=0.57$, $\mathrm{P}<0.05)$. In winter, the tone of the autonomic nervous system in cows has no significant correlations with calcium content in various blood fractions $(\mathrm{r}=0.24-0.51)$.

There is a significant dependence of calcium content in bovine blood on the tone of the autonomic nervous system in summer, while in winter, the tone of the autonomic nervous system does not reliably limit the content of this element in blood of animals (Table 3).

However, in summer, if the heart rate differences according to the results of the trigeminovagal test in cows changes by one unit, the content of ionized calcium in whole blood changes in the same way by 0.02 conditional units $(\mathrm{P}<0.001)$, and the ratio of ionized to total calcium in blood serum by 0.01 conditional units $(\mathrm{P}<0.05)$. Moreover, in summer, up to $75 \%(\mathrm{P}<0.001)$ of ionized calcium content and up to $33 \%$ $(\mathrm{P}<0.05)$ of variations in the ratio of ionized to total calcium in blood serum of cows can be caused by the tone of the autonomic nervous system of animals.

Unlike the tone of the autonomic nervous system, the season has a significant effect on calcium content in whole blood $(\mathrm{F}=8.94>\mathrm{FU}=7.41 ; \mathrm{P}<0.01)$, while the content of this element in the serum and blood cells of cows had no relationship with the season. Also, should be noted the significant influence of the vegetative status of animals on the content of ionized calci$\mathrm{um}$ in blood serum $(\mathrm{F}=6.19>\mathrm{FU}=3.55$; $\mathrm{P}<0.01)$. Thus, both the seasonand the tone of the autonomic nervous system did not affect the ratio of ionized to total calcium in blood serum $(\mathrm{F}=3.19-3.37<\mathrm{FU}=3.55-4.41$; $\mathrm{P}>0.05)$. Analyzing calcium content in various fractions of blood of cows, a significant relationship between the vegetative status of cows and the season was not established $(\mathrm{F}=0.25-1.94<\mathrm{FU}=3.55, \mathrm{P}>0.05)$.

Therefore, the tone of the autonomic nervous system and the time of year affect the content of calcium and phosphorus in blood of cows. 


\section{Regression analysis of the dependence of calcium content in blood of cows on the tone of the autonomic nervous system, conditional units $(n=16)$}

\begin{tabular}{|c|c|c|c|c|}
\hline \multirow{3}{*}{ Substrate } & \multicolumn{4}{|c|}{ Indicator } \\
\hline & \multicolumn{2}{|c|}{ summer } & \multicolumn{2}{|c|}{ winter } \\
\hline & coefficient & R-squared & coefficient & R-squared \\
\hline Whole blood & 0.01 & 0.09 & 0.01 & 0.10 \\
\hline Blood serum & 0.01 & 0.13 & 0.01 & 0.06 \\
\hline Blood cells & 0.0001 & 0.02 & 0.01 & 0.26 \\
\hline Ionized $\mathrm{Ca}^{++}$ & $0.02 * * *$ & $0.75 * * *$ & 0.01 & 0.16 \\
\hline Ionized $\mathrm{Ca} /$ total $\mathrm{Ca}$ & $0.01 *$ & $0.33^{*}$ & 0.15 & 0.214 \\
\hline
\end{tabular}

Note: differences are significant in comparison with normotonics: $* \mathrm{P}<0.05 ; * * \mathrm{P}<0.01$; $* * * \mathrm{P}<0.001$.

\section{Conclusions and future perspectives}

The tone of the autonomic nervous system in cows in summer is significantly inversely related to the content of phosphorus in whole blood $(\mathrm{r}=-0.73 ; \mathrm{P}<0.05)$, its cells $(\mathrm{r}=-0.87 ; \mathrm{P}<0.001)$ and directly correlates with the content of ionized calcium in serum $(r=0.87 ; \mathrm{P}<0.001)$. The regression analysis shown a significant effect of the autonomic nervous system tone on the content of ionized calcium in blood serum $(\mathrm{F}=6.19>\mathrm{FU}=3.55 ; \mathrm{P}<0.01)$.

\section{References}

Avtsyn, A. P. (1991). Mikrojelementozy cheloveka etologija, klassifikacija, organopatologii [Human microelementoses. etology, classificaton, organopathology]. Moscow: ONICS 21 century World.

Byts, H. O. (2010). Vykorystannja preparatyvnogo germanii v profilaktike gastrojenterivitov teljat. [The use of germanium preparations for prevention of gastroenteritis in calves]. Scientific Messenger of LNU of Veterinary Medicine and Biotechnologies. Series: Veterinary Sciences, 12(3(45)), 3-6. Vlizlo, V. V., Fedoruk, R. S., \& Ratych, I. B. (2012). Laboratorni metody doslidzhen $u$ biolohiyi, tvarynnytstvi ta veterynarniy medytsyni [Laboratory methods of investigation in biology, stock-breeding and veterinary]. Spolom, Lviv.

Gromova, O. A. (2010). Analiz molekuljarnyh mehanizmov vozdejstvija zheleza (II), medi, marganca $v$ patogeneze zhelezodeficitnoj anemii [Analysis of the molecular mechanisms of the effects of iron (II), copper, manganese in the pathogenesis of iron deficiency anemia]. Clinical Pharmacology and Pharmacoeconomics, 156.

Gapon, V. O., \& Yashchenko, A. B. (2005). Marganec' u navkolishn'omu seredovishhi ta jogo vpliv na organizm [Manganese in the middle of the middle of the yoke for organism]. Dovkillya zdorov'ya, 2(33), 69-72.

Guyot, H., Klinkon, M., Jezek, J., \& Staric, J. (2012). Diagnostyka deficita mikrojelementov u zhvachnyh zhivotnyh [Trace minerals deficiency diagnosis in ruminants], In Proceedings of the 14th Conference of the European Soc. of Veterinary Clinical Pathology, 45-50.

Grushanska, N., \& Kostenko, V. (2017). The biochemical indicators of sows' blood at the prevention of mineral metabolic disorders. Scientific Messenger of LNU of Veterinary Medicine and Biotechnologies. Series: Veterinary Sciences, 19(82), 71-76. https://doi. org/10.15421/nvlvet8215

Zakharenko, M. O. (2004). Rol' mikroelementiv u zhittedijal'nosti tvarin. [The role of micro- 
elements in living creatures]. Veterinary medicine of Ukraine, 2, 13-16.

Zinko, H. (2017). Immunnyj status teljat, bol'nyh gazotrojenteritom [Immune status of calves sick with gastroenteritis]. Scientific Messenger of LNU of Veterinary Medicine and Biotechnologies, 19(82), 61-65. doi: $10.15421 /$ nvlvet8213.

McDowell, L. R. (2003). Mineraly v pitanii zhivotnykh i cheloveka. [Minerals in animal and human nutrition]. Elsevier Health Sciences. doi: 10.1016/B978-0-444-51367-0.X5001-6.

Kalyn, B. M. (2011). Zastosuvannja helatnyh spoluk mikrojelementiv u hodivli tvarin: metodichni rekomendacii [The use of chelated compounds of trace elements in animal nutrition. Methodical recommendations are approved and recommended for publication by the Scientific and Technical Council of the Ministry of Agrarian Policy of Ukraine. Lviv. Marushko, Yu. V. (2013) Znachennja porushen' vmistu margancju u klinichnij praktyci [Significant damage of Manganese content in clinical practice]. Children's doctor 4(25).

Pogorlov, M. V. (2010). Makro- ta mikroelement (obmin, patologija ta metodi viznachennja): monografija. [Macro of microelements (exchange, pathology and methodology): monograph] Sumi: Sumdu. Skalny, A. V. (2004). Himicheskie jelementy v fiziologii i jekologii cheloveka [Chemical elements in physiology and ecology person]. Moscow: ONICS 21 century World.

\section{В. Журенко, В. І. Карповський, В. В. Журенко (2021). РОЛЬ АВТОНОМНОї НЕРВОВОЇ СИСТЕМИ В РЕГУЛЯЦІї ОБМІНУ ФОСФОРУ ТА КАЛЬЦІЮ В КРОВІ KOPIBO. Ukrainian Journal of Veterinary Sciences, 12(2): 38-45,} https://doi.org/10.31548/ujvs2021.02.004

Анотація. Провідну роль у мобілізації адаптаційних можливостей організму відіграють нейро-гуморальні механізми, насамперед - діяльність центральної нервової системи. Повноцінність мінерального живлення великої рогатої худоби залежить від забезпеченості тварин макроелементами, які входять до структури багатьох ензимів або єїх активаторами, приймаючи провідну роль в окисно-відновних реакціях. Досліди проводили на коровах української чорно-рябої молочної породи 2-3 лактачії. За результатами дослідження тонусу автономної нервової системи було сформовано 3 дослідні групи: I - нормотоніки, II - ваготоніки, III - симпатикотоніки. Відбір крові проводили двічі на рік, влітку та взимку. Цільну кров стабілізували за допомогою гепарину, сироватку крові отримували методом відстоювання, а клітини крові-за допомогою центрифугування гепаринузованої крові, відбирання плазми та триразового промивання клітин у холодному ізотонічному розчині з наступним центтифругуванням. Тонус автономної нервової системи в корів влітку достовірно обернено пов'язаний із вмістом Фосрору в цільній крові $(r=-0,73 ; P<0,05)$ та їі клітинах $(r=-0,87 ; P<0,001)$. Тоді, яку сироватиі крові дані взаємозв'язки недостовірні, як влітку так і взимку $(r=-0,02-0,24)$. Взимку тонус автономної нервової системи в корів обернено достовірно пов'язаний лише з вмістом Фосфору в цільній крові $(r=-0,81 ; P<0,01)$. На відміну від тонусу автономної нервової системи пора року має достовірний вплив на вміст Кальцію в цільній крові $(F=8,94>F U=0,41 ; P<0,01)$, тоді, як вміст цього елементу в сироватці та клітинах крові корів не залежав від пори року.

Отне, тонус автономної нервової системи та пора року впливають на вміст Кальцію $i$ Фосрору в крові корів.

Ключові слова: корови, кров, нервові процеси, тонус автономної нервової системи, Кальчій, Фосфор 